EDITORIAL

\title{
Las ciencias biomédicas del siglo XXI Critica al Determinismo Genético
}

\author{
Luis Gustavo Celis ${ }^{1}$
}

\begin{abstract}
1. Biólogo Investigador, Curso de Especialización en Inmunología, Especialista en Inmunología, Especialista en Bioética, Especialista en Prospectiva y Estrategia Organizacional, Magíster en Biología con énfasis en Genética Humana.
\end{abstract}

El Dr. Luis Gustavo Celis se desempeña, entre otros cargos, como Profesor de las universidades colombianas Los Andes, UDCA, La Sabana y Externado en materias relacionadas con Medicina, Biotecnología, Genética, Biología y Ecología en pregrado y posgrado; Planificador del Consejo Nacional de Investigaciones Científicas y Tecnológicas (CONICIT), Caracas, Venezuela; Asesor del Programa de Prospectiva Tecnológica en Biotecnología del Instituto de Biomedicina de la Universidad Nacional de Colombia, Santafé de Bogotá, Colombia; Consultor del Programa Multinacional de Biotecnología y Tecnología de Alimentos de la Organización de Estados Americanos (OEA) - Colciencias; Coordinador de la Cátedra de Genética y del Diplomado de Biología Molecular de la Facultad de Medicina de la Universidad de La Sabana; Par Académico designado por la Asociación Colombiana de Facultades de Medicina (Ascofame) para la aplicación de los Exámenes de Calidad para la Educación Superior (ECAES), Secretario de la Asociación Colombiana de Genética Humana (Acgh) y Tesorero de la Asociación Latinoamericana de Mutagénesis, Carcinogénesis y Teratogénesis Ambiental (ALAMTA).

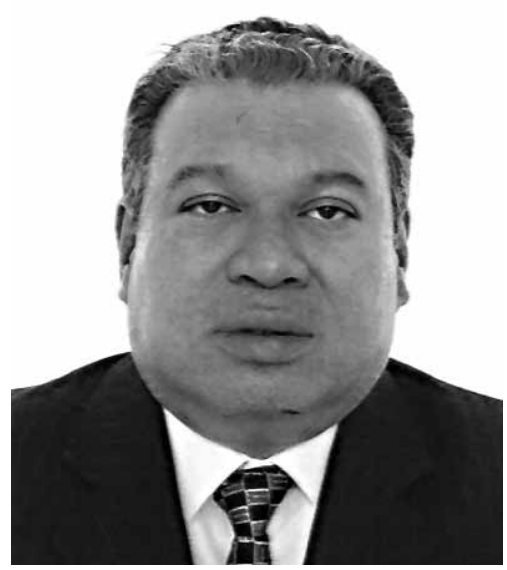

$\mathrm{E}$ 1 conocimiento es un misterio fascinante en la actualidad, es poder y dominio. Un ejemplo manifiesto de esto es el Proyecto Genoma Humano, el cual busca identificar y cartografiar esos aproximadamente 25.000 genes que conforman el genoma humano. Este estudio tiene nobles intenciones en el futuro podríamos abaratar medicinas costosas, aliviar el hambre que padece gran parte de la humanidad, corregir defectos genéticos o detener el deterioro microambiental, pero además es un poderoso instrumento para intervenir la vida humana aún antes de la procreación (tecnofecundación) y una herramienta para diseñar organismos patógenos extraordinariamente virulentos o del producir hombres a la medida.

La Biomedicina por tanto debe estar al servicio del hombre no para dominarlo, no para transformarlo en cosa o negocio. Las decisiones humanas constituyen el campo específico de la reflexión ética, la ciencia y la técnica son acciones y por lo tanto están sujetas a la reflexión ética, además de que estas acciones pueden ser buenas o malas, por lo tanto el progreso no puede ser autónomo, el científico no es neutro, los experimentos que involucren seres vivos capaces de sentir como ocurre en la investigación biomédica necesariamente conducen a una reflexión Bioética.

Los problemas éticos derivados de la investigación genética están en plena efervescencia en el momento actual, la investigación del genoma se están convirtiendo en un nuevo foco del capitalismo, transformando la ética en monética y dando origen a una nueva fiebre del oro, porque las grandes compañías han percibido la importancia de patentar los genes humanos (lo cual ha dado origen a una gran controversia), motivado a que partir de estos debe desarrollarse la biomedicina del siglo XXI, generándose nuevos elementos tanto diagnósticos como terapéuticos. 
Otra grave preocupación que ha surgido de estas investigaciones es el determinismo genético basado en una excesiva genomización del hombre, que pretende explicar todas sus dimensiones a partir de sus genes, así tenemos el gen del egoísmo, de la delincuencia, de la obesidad, de la violencia, de la homosexualidad y otros, si bien la parte biológica del hombre (incluyendo la genética), es muy importante, no se puede atribuir todas las conductas del hombres a ellas, esto eliminaría la responsabilidad individual de cada uno y se perdería el sentido de la ética, quedando reducido todo a lo que tenemos en los genes. Después surgiría la eugenesia genética embrionaria, porque podríamos desechar a los individuos que porten características no deseadas o que no estén de acuerdo a la moda o al estereotipo actual, en este caso estaríamos haciendo selección positiva o negativa de individuos, todo esto nos conducirá a una genocracia, en donde el poder de los genes será una dictadura y todo lo que esté por debajo de lo normal va camino al despeńadero, como los aguerridos Espartanos de la antigua Grecia que arrojaban por los desfiladeros a los niños deformes, en el siglo XXI los arrojaremos al precipicio genético, por ejemplo cuando seleccionamos de acuerdo a nuestro interés un determinado genotipo no deseado.

En este momento hacemos un alto en el camino y declaramos que el hombre no es propiedad de la genética, el reduccionismo biológico no enaltece al hombre sino que lo despoja de su libertad, por lo tanto serían inútiles las campañas preventivas de enfermedades como el alcoholismo, la igualdad de oportunidades o la de educación para todos, dado que todo está determinado de antemano (sobre todo en los genes), de no reflexionar y actuar rápidamente, el hombre asumirá, sino lo ha hecho ya el papel del Creador.

En este orden de ideas el determinismo genético constituye una gran falacia que pretende dejar de lado la responsabilidad individual para sustituirla por un factor inmutable y determinado que son los genes. Esto nos conlleva a un concepto univoco del instinto y que no toma en cuenta la heterogeneidad del mismo, donde el ambiente tanto biológico como cultural interaccionan con los genes y modelan elementos como lo irascible y lo concuspicible.

Cuando se desconoce esta dimensión del hombre y se le reduce a un plano meramente biológico se justifican todo tipos de conductas como la infidelidad (deseo serte fiel pero estos genes que llevo dentro me alborotan), la homosexualidad, que si bien algunos trastornos cromosómicos pueden llevar a una ambigüedad sexual, muchos de los casos reportados son de tipo adquirido por fenómenos como el hacinamiento en las cárceles, la falta de una figura paterna en la educación o una educación sexual centrada tan sólo en la prevención de enfermedades de transmisión sexual y los embarazos no deseados.

Otra conducta que se pretende justificar con base a estos argumentos son los fenómenos delincuenciales, reducir la conducta delictiva a un fenómeno netamente biológico y genético puede conducir a una sociedad a estigmatizar a los sectores más vulnerables y desposeídos de la población, justificándose prácticas como el aborto y la esterilización como formas de evitar que genes indeseables aparezcan o se difundan en la población.

A lo largo de estas líneas hemos pretendido mostrar que el determinismo genético es una gran falacia ética que busca liberar al hombre de su propia responsabilidad individual y atribuir a una esfera netamente biológica la causa primaria de todas las conductas humanas, desconociendo una dimensión importante del hombre basada en la racionalidad y por ende de la voluntad producto de la participación de la naturaleza humana en el SER divino. 